\title{
The image of an employee in Russian psychological studies: a desk study
}

\section{Estudio de la imagen del empleado en estudios psicológicos rusos: un estudio teórico}

\author{
Shilova Tamara \\ Moscow city pedagogical University, Moscow, Russian Federation \\ ORCID ID: https://orcid.org/0000-0002-8881-2948
}

\section{Polyanskaya Ekaterina}

Pirogov Russian National Research Medical University, Moscow, Russian Federation Peoples' Friendship University of Russia (RUDN University), Moscow, Russian Federation

ORCID ID: https://orcid.org/ 0000-0003-2999-1082

\section{Babaev Tosif}

Peoples' Friendship University of Russia (RUDN University), Moscow, Russian Federation

ORCID ID: https://orcid.org/0000-0002-4860-0377

\section{Received 10-10-20 Revised 11-12-20 Accepted 01-13-21 On line 01-14-21}

\section{*Correspondence}

Email: olfiss@list.ru
Cite as:

Shilova, T., Polyanskaya, E., \& Babaev, T. (2021). The image of an employee in Russian psychological studies: a desk study. Propósitos y Representaciones, 9 (SPE1), e861. Doi: http://dx.doi.org/10.20511/pyr2021.v9nSPE1.861 


\section{Summary}

The article covers the background of Russian psychological studies on the image of an employee. The article deals with the self-concept as a building block of the image of an employee. The author analyzes the role of professional self-determination, motivational characteristics and mental regulators in creating the image of an employee.

Keywords: image, employee, self-concept.

\section{Resumen}

El artículo examina la historia del estudio de la imagen del empleado en los escritos de psicólogos rusos, considera el "Yo - concepto" como un componente formador de estructuras en la imagen del empleado. Analiza el papel de la autodeterminación profesional, las características motivacionales y los reguladores mentales en el modelado de la imagen del empleado.

Palabras clave: imagen, empleado, "Yo-concepto".

\section{Introduction}

The social and economic changes in the Russian society in recent decades have made it necessary to study a person as a subject of professional activity and their involvement in work processes. An employee's personal success, attitude to work, as well as their image of a work largely depends on their vocational, psychological and legal training. Sociologists, vocational guides and trainers pay a special attention to the way that professional activity influences an employee's personal traits (Klimov 1988, Pryazhnikov \& Kamneva \& Polevaya 2016).

Organizational psychology and labor psychology studies have had a great impact on the image of an employee and the work (Klimov 1988, Grachyov 2013, and others).

The psychological research is aimed at studying the factors which create the image of an employee, socially adequate and value-oriented fora specific profession.

Studying the image of an employee is closely linked to the idea of efficiency as the proportion of employees' unrealized potential to the full range of their abilities.

\section{Methodology}

The author used theoretical methodology such as deductive, inductive and comparative methods.

\section{Background}

Nowadays psychologists, sociologists and pedagogues are highly interested in the issues, related to the study of an employee as a subject of labour relations (Avdonina 2017; Artemyev \& Solntsev \& Tserfus 2011; Buldakova 2012; Galushchinskaya 2018; Grachyov, 2008-2018; Guryan 2013; Efremov 2000; Klimov 2018; Knyazev \& Lyubimova 2012; Kuznetsova 2017; Rigel 2018; Rodionova 2013; Timofeeva \& Pavlova 2017; Tyurina \& Komissarova 2011; Ustinova 2014; Shirinskaya \& Lomakova \& Fokin 2016; Yurganova 2005). Professionalization has become an important goal not only for the society, but for a person themselves. Moreover, professional self-development is considered the main component of a mature person.

Studying the image of an employee and their personal traits is both a traditional issue and a relatively new problem in Russian psychological studies.

R.A. Voyko (2011), S. Gabrchek (2018), L.E. Gavrilyuk (2018) studied the psychophysiological aspects of an employee's self-development and mental functions. They proved that self-concept, which reflects a person's characteristics within the real relations he/she is involved in, contributed a lot to the studies linked to the image of an employee. Its center is the formation of personality and its development, which regulates mental life and the self-image system, being an actual personal inner core. 


\section{Discussion}

\section{Self-concept as a determinant for the image of an employee}

Professional self-concept determines professionalization and the success in professional activity, as well as professional integration into society and professional community. The descriptive part of self-concept is called a self-image, which reflects an employee's attitude to themselves or their own qualities. Self-concept consists of cognitive, evaluative and behavioral aspects. Thus, self-image can be related to a person's level of activity. Self-image is divided into a real image (the way a person sees themselves) and an ideal image (the desired image of themselves).

The development of cognitive studies provided the acknowledgement of the cognitive aspect. Therefore, labor psychology has gained the terms of a professional worldview, an operational image, an image of work. Hence, an individual gains a certain image system regulating their behavior. A.A. Grachyov, there is the terminal image which is related to the final life values. One should distinguish the terms of 'social image' and the terminal image. While the terminal image is individual, the social image is a collective phenomenon.

Specifics of the terminal images.

Consider the specifics of the terminal images:

1) Dependence on a person's life orientation. A person tends to follow their life orientations in any situation by identifying the ideas they need to implement in their life;

2) Regulative function. A person forms their own ideal and real self-images, the abilities and the actions which would provide the transformation of the real into the ideal, and the results of this transformation (Grachyov 2013, p. 238). Every employee has their self-image, which is largely linked to the problems of professional self-determination (Baranov 2016; Guseynova \& Guseynova 2017; Gushchina 2008; Solntseva \& Zak 2017; Faas 2019).

\section{The role of professional self-determination in the formation of an emloyee's image}

According to V.N. Knyazev and E.A. Lyubimova, professional self-determination is "a complex, multi-dimensional and sometimes contraversial process, based, on the one hand, a person's natural desire to be self-independent which presupposes their active position during the whole process, and, on the other hand, a focus on social values. Therefore, there are psychological and sociological approaches to study of self-determination" (Knyazev \& Lyubimova 2012, p. 37). We must point out that professional self-determination is not confined within a specialist's professional sphere. It is a long process which starts from the stage of professional selfdetermination itself and lasts till the end of professional activity. The formation of an employee's personality begins at the stage of vocational training which means specialized vocational education. Its end does not mean the end of professional self-determination. Professionalism should be considered not as achieving high results in the professional activity, but as a set of appropriate psychological components. Organizational activity presupposes a self-perception as a part of the organization. A.A. Grachyov considers the image of an employee as a part of a roleplay. By imagining themselves as a professional, an employee plays the roles of a chief, a collegue and a subordinate. Every employee plays these roles according to their individual psychological characteristics. The criterion of a successful role-play is work efficiency which depends on an employee's motivation and abilities (Grachyov 2018, p. 49-50).

V.T. Kudryavtsev reckons that professionalization has four stages:

1) formation of professional intentions;

2) vocational training;

3) professional integration;

4) a person's partial or complete fulfillment (Kudryavtsev \& Shegurova 1983).

E.A. Klimov (2008) names the following stages of professionalization:

1) an optant (a person who chooses their profession);

2) an adept (a person who learns their profession); 
3) an adaptant (a person who started their professional activity);

4) an internat (a person who has got integrated into professional community);

5) a master (a person who has developed professional skills and expertise);

6) an authority (a person who has high-level professional skills and expertise);

7) a mentor (a person who has no physical ability to continue professional activity, but still is able to transfer his experience).

Thus, a professional development is a complex process. A.A. Grachyov supposes that a person is a subject of professional activity, business interactions and organizational activity (Grachyov 2018, p. 49).

Personal development is wider than professional one and determines the attitude to a profession. We agree to Klimov and define professional self-determination as 'self-determination of a professional', 'self-determination of a young person - a future professional'. Klimov considers 'professional self-determination' an activity which has certain content according to the stage of a person's development as the subject of work. The process of a person's development as the subject of work has several stages related to the profound emotional experiences (Klimov 2008). The key factors of professionalization are "motivation, skills, an image of work and work culture. They correspond to the criteria of efficient work behavior (motivation - level of implementation of life orientations, skills - work efficiency, image of work - productivity of the work image, work culture - an employee's appropriateness for work culture)" (Grachyov 2018, p. 44-45). Therefore, a sum of individual psychological characteristics determines a person's professional orientation and their motivational sphere.

\section{Motivational characteristics of an employee's image}

A.A. Grachyov names three groups of an employee's motivational characteristics:

"1) Deficient characteristics: a focus on a private gain; an interest in meeting material needs; a wish for a simple, well-organized and secure job; a willingness to have a favorable position in the group; a desire for recognition and high assessments from authorities; a desire to influence the productive life; a desire to relax at work as long as possible, with lesser efforts made.

2) Self-realizing characteritics: an interest in doing difficult, but reasonable work tasks; a desire to do the best work; a great involvment into work; an employee's attitude to work as a part of themselves; an interest in an antensive and profound communication with colleagues; a display of a broad cognitive interest in work.

3) Spiritual: an attitude to work as a means of self-improvement; an attitude to work as a meaning to life; a sense of duty and high moral responsibility for the work; a wish to help colleagues selflessly; a readiness for a full self-devotion to work and self-sacrifice for the work" (Grachyov 2018, p. 33-34).

Consider the role specifics of an employee (Table 1).

Table 1

Characteristics of employee (according to A.A. Grachyov)

\begin{tabular}{|c|c|c|c|}
\hline Role & Motivation & Skills & Image of work \\
\hline Employee & $\begin{array}{l}\text { Focus on the values of } \\
\text { the organization, } \\
\text { loyalty to the } \\
\text { organization, } \\
\text { readiness for a civic } \\
\text { behavior }\end{array}$ & $\begin{array}{l}\text { Organizational skills } \\
\text { (the ability to optimize } \\
\text { organizational } \\
\text { environment and } \\
\text { organizational } \\
\text { situations) }\end{array}$ & 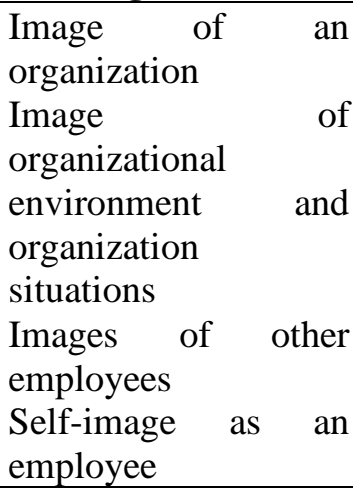 \\
\hline Professional & $\begin{array}{l}\text { Motivation for a } \\
\text { professional activity, } \\
\text { love for the profession }\end{array}$ & $\begin{array}{l}\text { Professionally } \\
\text { important skills }\end{array}$ & $\begin{array}{l}\text { Professional } \\
\text { worldview } \\
\text { Conceptual model }\end{array}$ \\
\hline
\end{tabular}




\begin{tabular}{|l|l|l|l|}
\hline Chief & $\begin{array}{l}\text { Managerial } \\
\text { motivation }\end{array}$ & Managerial skills & Operational image \\
\hline Subordinate & $\begin{array}{l}\text { Performing } \\
\text { motivation }\end{array}$ & Performing skills & Performing concept \\
\hline Colleague & $\begin{array}{l}\text { Communicative } \\
\text { motivation }\end{array}$ & Communicative skills & $\begin{array}{l}\text { Image of a colleague } \\
\text { Self-image as a } \\
\text { colleague }\end{array}$ \\
\hline
\end{tabular}

As a result, professionalization shapes the personality of a professional, who is able to develop their natural potential and achieve mastery. The image of an employee is influenced by, firstly, the level of the closest social environment which provides the support of material living (family) and the comprehension of social codes and values, secondly, the level of social and occupational organization (companies and institutions where people are united with a joint labor activity), related to material and spiritual values, and, lastly, the level of state organization and social organization in general (Grachyov 2007, p. 10-11).

Nowadays there are three approaches to study of psychological climate in the activity:

1) analysis of profession as a psychological compound which contains requirements for the activity and its performers;

2) analysis of the subject of the activity, aimed at identifying the aspects of work conditions which display most vividly the subjects' personal characteristics;

3) analysis of professionalization among the subjects of the professional activity as a more full expression of its psychological aspect.

We must point out that an employee's national mentality plays a vital role in the professional self-development. A.A. Grachyov states that national mentalities are based on work ethic. We are interested in Orthodox work ethic which postulates that every labor is aimed at reaching the highest value. The mentality of an employee as a bearer of organizational culture includes:

“- an employee's attitude to their company and the company's attitude to their employee;

- an image of a company (real and ideal images): the idea of reasonable organizational values, goals, principles and problems; the image of organizational environment and typical organizational situations;

- an image of an employee (typical and ideal)

- an image of an employee's behavior in the main organizational situations (typical and ideal)" (Grachyov 2018, p. 42).

The problem of studying the interrelations between the idea of an employee and their personal traits is the result of the problem of professional self-determination and personal development. The image of an employee is influenced by organizational culture. A.A. Grachyov names three categories of the terminal images:

1) a self-image or someone else's image - a portrait;

2) an image of environment - a thematic picture;

3) an image of a situation - a drama (Grachyov 2013, p. 238).

The transformation of a professional activity into a higher-level activity depends on a person's social and economic environment and their ability to overcome life obstacles.

Mental work regulators as an important component of an employee's image

A personal life orientation is determined by life values. A personal life orientation is the integrity of a personal quality which regulates a person's activity (N.V. Mekhonoshina 2015).

A.A. Grachyov conducted his own analysis and identified three main life orientations: deficient, self-realizing and spiritual ones.

The deficient life orientation is characterized, firstly, by the focus on the result as a reward or punishment related to a desire for using certain objects to achieve goals; secondly, by assessment linked to the search of the most useful objects; lastly, a wish for comfort. The self- 
realizing life orientation is related to a person's desire to realize their potential, manage comprehensive tasks and 'feel the flow'.

Spiritual life orientation is linked to the achievement of humanistic values (kindness, beauty, truth), a desire to serve other people and experience higher feelings (Grachyov 2007, p. 13).

Values are crucial for the cohesion of the employees from different office departments and the organization management level (Klimanova \& Shaymukhametova 2016). Values shape integrity of views and actions and, thus, provide effective achievement of the organizational goals. A set of values obtained by employees constitutes its value basis, so every employee has their own position in the system of general organizational values. Each person has their own set of values but their positions change due to the relationship with colleagues and value exchange. Stereotypes about employees play a key role in the acceptance of organizational values. An employee's self-identification with their company means that the employee accepts the ideals of their company and obeys its rules and codes. Work regulators are also important there.

E.A. Klimov names the following mental work regulators:

- an image of work object: a sensory image (a perceptive image), an exact image (the ideas kept in memory or created with imagination), a representative abstract image (notions, schemes);

- an image of work subject: a relevant self-image (an employee's acknowledgement of their relevant status and real position among the others), a generalized self-image (a self-concept, which includes an employee's self-image in their past, present and future); a self-image as a representative of a professional community and the profession itself;

- an image of object-subject and subject-subject relations: an employee's realization of their own needs, emotions, and life orientation (Klimov 2018).

Another important aspect is social professional self-identification which means an interrelation of a profession and a professional's psychological characteristics. Therefore, a profession influences professionals' consciousness and self-consciousness, their self-esteem and the whole relation system. Every profession has certain requirements such as age, health condition, body type, etc. (Klimov 2018). When studying value system, one should pay attention to the internal conditions of activity. Work effectiveness is an employee's key quality. Thus, the main condition of an employee's success is the ability to realize their life orientations. It is divided into three clusters of skills which correspond to life orientations:

1) Deficient skills are related to meeting of material needs, trying to stay safe at work, and establishing of good relationships with colleagues, subordinates and chiefs.

2) Self-realizing skills presuppose an employee's assessment of their praxical, cognitive and communicative potential.

3) Spiritual skills mean an employee's ability to create their own work philosophy and identify their own place in the work system.

In addition, the professionally important skills include an employee's general skills which correspond to the three types of activity: praxical, cognitive and communicative (Grachyov 2018, p. 35).

According to A.A. Grachyov, the image of work is terminal. From his desk study and experimental research there come the following conclusions; "1) Social well-being is a component of a person's behavior-regulating system: being a emotion-setting state, it is based on perception and assessment of a person's environment and determines their important life choices.

2) Social well-being is characterized by: a) the domination of social sphere in a person's life (family, work, etc.) and b) a person's subjectivity level. A person shows their full subjectivity in the most important sphere of life.

3) The perception and assessment of the environment are determined with a person's life orientations. Therefore, social well-being is closely linked to the realization of a person's life orientations in his main spheres of life.

4) Being a part of an organization is one of the most important spheres of a mature person's life" (Grachyov 2008, p. 12).

\section{Conclusiones}


To sum up, image is the key category which provides an employee's personal development. Its structure consists of cognitive, evaluative and behavioral aspects. The image of an employee is split into a real one (the one they already have) and an ideal one (the one they want to have). The terminal image is an image related to a person's life orientations and regulative function.

Organizational psychology, labor psychology and personal psychology deals with the image of an employee as the modern post-industrial society has higher requirements for employees.

Each employee plays a certain role in their company: an employee, a professional, a chief, a subordinate, a colleague. Professional development in the context of motivation and skills is a crucial part of a personality. An employee's motivational sphere is determined with a focus on organizational values, love for work, a readiness to manage, to do tasks, to communicate according to organizational goals and targets. An employee's skills are linked to the ability to optimize an organizational environment, acquire professionally important qualities focused on management, coping with work tasks, and communication.

\section{References}

Avdonina, N.S. (2017) The determination of building blocks in a professional identity. Newsletter of Omsk State Pedagogical University. Humanitarian research. No 3 (16), Omsk, Russia, 127-131

Artemyev, N.A. \& Solntsev, V.O. \& Tserfus, D.N. (2011) Differentiated approach to the identification of professionally important qualities in different specialities. Problemy upravleniya riskami $v$ tekhnosfere [The problems of risk-management in the technosphere]. No 3 (19), 112-118

Baranov, A.E. (2016) Professional education of a pedagogue: identifying the content. Ezhegodnaya bogoslovskaya konferentsiya Pravoslavnogo Svyato-Tikhonovskogo gumanitarnogo universiteta [Annual Theological Conference at St. Tikhon's Orthodox University]. No 26, 251-254

Buldakova, N.V. (2012) Identification of professionally important qualities among the social and humanitarian department students. Theoretical and practical scientific and educational challenges in the 2th century: Collection of academic papers from International Correspondence Scientific-Practical Conference in $10 \mathrm{vol}$. [Teoreticheskie i prikladnye problemy nauki i obrazovaniya $\mathrm{v} 21$ veke], $15-20$

Efremov, E.G. (2000) Defining professional self-consciousness. Siberian Journal of Psychology. No $12,110-118$

Faas, O.V. (2019) Identifying professional involvement of potential HRs. Sovremennye tekhnologii upravleniya personalom: ot problem $k$ resheniyu [Modern management technologies: from problems to their solutions. Collection of academic papers from International Scientific-Practical Conference]. Ed.: I.V. Rezanovich. Chelyabinsk, 59-63

Gabrchek, S. (2018) Identifying a Croatian teacher's professional competences. Tendentsii razvitiya obrazovaniya: kto i kak ispol'zuet i otsenivaet obrazovatel'nye standarty [Tendencies in the development of education: the use and assessment of educational standards/ Materials from XIV Annual Scientific-Practical Conference]. The Russian Presidential Academy of National Economy and Public Administration, MSSES, 77-101

Galushchinskaya, O.Yu. (2018) Identifying the structure of a pedagogue's professional and personal potential. Sovremennoe obrazovanie: metodologiya, teoriya i praktika [Modern education: methodology, theory and practice. Materials from International ScientificPractical Conference]. Shadrinsk State Pedagogical University, 326-332

Gavrilyuk, L.E. (2018) Qualitative criteria and invariant qualities of professional readiness and its place in professionalization. News of Science and Education. Vol.3, No 3, 24-28

Grachyov, A.A. (2008) Life orientations in practical psychological personal concepts. Izvestia: Herzen University Journal of Humanities \& Sciences. No 66, 289-294 
Grachyov, A.A. (2008) Motivational image of a Russian employee in the psychological design of organizations. Izvestia: Herzen University Journal of Humanities \& Sciences. No 59, $27-$ 32

Grachyov, A.A. (2008) Organizational factors of satisfaction from work and life among workers and employees. Izvestia: Herzen University Journal of Humanities \& Sciences. No 62, 225230

Grachyov, A.A. (2018) Psychology of an employee: organizational approach. Psikhologiya truda $i$ upravleniya kak resurs razvitiya obshchestva $v$ usloviyakh global'nykh izmeneniy [Occupational psychology and nanagerial psychology as a source of social development in the conditions of global changes: materials from International Scientific-Practical Conference on the 25th Anniversary of Psychology Department], Tver State University, Tver, Russia, 49-55

Grachyov, A.A. (2018) Psychology of an employee in the subject field of organizational psychology. Scientific e-journal "Russian Academy of Science Institute of psychology. Organizational Psychology and Labor Psychology". Vol.3. No 4, 30-48

Grachyov, A.A. (2013) Theoretical and methodological basis of applied psychology. Psychological Journal. Vol.34, No 1, 15-24

Guseynova, E.L. \& Guseynova, A.R. (2017) Identifying the cognitive development level of students' professional competences. Aktualnye voprosy vysshego professionalnogo obrazovaniya [Relevant problems of higher education: collection of academic papers from International Scientific-Methodological Conference], 149-153

Gushchina, G.A. (2008) The main approaches to the definition of professional culture in the context of social and pedagogical analysis. Vestnik Moskovskogo gosudarstvennogo universiteta kultury i iskusstv. No 5, Moscow, Russia, 127-130

Klimanova, N.G. \& Shaymukhametova, S.F. (2016) Life values and motivation for activity among enterpreneurs and employees. Innovative economics: prospects for development and upgrade. 2016, No 5 (15), 64-71

Klimov, E.A. (1988) Introduction into the labor psuchology. Moscow, Russia, 199

Knyazev, V.N., Lyubimova, E.A. (2012) Defining professional self-determination. Vestnik NOU ONUTC Gasprom, No11, 37-40

Kuznetsova, N.V. (2017) Identifying the key competences in vocational training of management department students. WORLD SCIENCE: PROBLEMS AND INNOVATIONS (materials from XVI International Scientific-Practical Conference in 3 vol.), 211-214

Lukyanova, Z.V. (2007) Formation of professional value system among te furture medical specialists. Vestnik Bashkirskogo universiteta. Vol. 12, No 4, 216-218

Mekhonoshina, N.V. (2015) The structure of work values among industrial workers. Master's Journal. No 2, 257-263

Pryazhnikov, N.S. \& Kamneva, E.V. \& Polevaya, M.V. (2016) Contradictions in identifying professional hazards // Humanities scientific researches, No 9 (61), 222-224

Rigel, E.G. (2018) Approaches to the definition of professional competence. Uchim upravlyat $i$ uchimsya upravlyat [Learning and teaching how to be a manager: materials from IV Scientific-Practical Conference for pupils, students and teachers, with foreign guests], 29

Rodionova, E.A. (2013) Subjective approach to the definition of professional success. Sotsialno-ekonomicheskie $i$ psikhologicheskie problemy upravleniya [Social and economic psychological management problems: materials from I (IV) International Scientific-Practical Conference, Moscow State University of Psychology and Education], 295-308

Shirinskaya, N.E. \& Lomakova, Ya.F. \& Fokin, A.E. Primary vocational guidance: professional self-determination among ninth graders. Nauka. Universitet. [Science. University. Materials from XVII Annual International Scientific-Practical Conference for professors, undergraduates and graduates], 55-59

Solntseva, N.V. \& Zak, G.G. (2017) Pedagogical monitoring of a high school children's readiness for a professional self-determination. Izuchenie $i$ obrazovanie detey s razlichnymi formami dizontogeneza $v$ usloviyakh realizatsii FGOS [Studying anв teaching children with different forms of disontogenesis in the conditions of Federal State Educational Standards: materials from Russian Scientific-Practical Conference for undergraduates, graduates and alumni], 292-295 
Timofeeva, M.S. \& Pavlova, L.V. (2017) Identifying the structure of professional pedagogical skills among future foreign language teachers. Nauka, obrazovanie, obshchestvo: tendentsii i perspektivy razvitiya [Science, education and society: tendencies and prospects of development. Materials from VIII International Scientific-Practical Conference]. Eds.: O.N. Shirokov et al., 143-146

Ustinova, L.V. (2014) Psychological specifics and tendencies in professional selfdetermination of young people. Russian science and education: problems and prospects. No 3 (2), 73-75

Voyko, R.A. (2011) The definition of the notion and the structure of a profession-oriented lifestyle of future pedagogues. Nauka i Sovremennost [Science and Modern Times], No 9-1, 195200

Yurganova, E.B. (2005) The display of professional self-consciousness specifics in identification of professional positions. Polzunovsky vestnik. No 3, 154-157

*The publication has been with the support of the "RUDN University Program 5-100". 